\title{
In-vitro antioxidants, antimicrobial and toxicological evaluation of Nigerian Zingiber officinale
}

Abubakar A. Yusuf ${ }^{1,4}$, Bashir Lawal ${ }^{2^{*}}$ (D), Asmau N. Abubakar ${ }^{2}$, Eustace B. Berinyuy ${ }^{3}$, Yemisi O. Omonije $^{2}$, Sheriff I. Umar ${ }^{2,4}$, Mohammed N. Shebe ${ }^{2}$ and Yusuf M. Alhaji ${ }^{2}$

\begin{abstract}
Background: Zingiber officinale is a rhizome commonly consumed as a delicacy, medicine or spice. It is considered as a safe spice with several medicinal properties. The aim of this study was to evaluate in-vitro antioxidants, antimicrobial and safety of Nigerian Z. Officinale.

Methods: Methanol extract of Nigerian Z. Officinale (MEZO) was evaluated for phytochemical composition, total flavonoids and phenol contents using standard procedures. Antibacterial study was carried out via the agar well diffusion method. Antioxidant activities were carried out using 2, 2'- diphenyl-1- picrylhydrazyl (DPPH), and ferric reducing antioxidant properties (FRAP) assay. Twenty five (25) wister rats were randomly grouped into five (A-E) of five animals each. Animals in Groups A-D were orally administered 75,150, 300 and $600 \mathrm{mg} / \mathrm{kg}$ bwt of the extract on daily basis for 4 weeks while those in Group A (control) received distilled water.

Results: Total phenolic and flavonoids contents of the extract were $15.24 \pm 0.02 \mathrm{mg} \mathrm{GAE} / \mathrm{g}$ and $19.84 \pm 0$. $32 \mathrm{mg} / \mathrm{g}$ CE respectively. The extract promoted an inhibition of free radicals with $I_{50}$ values of $47.05 \pm 2$. $03 \mu \mathrm{g} / \mathrm{mL}$ and $89.15 \pm 0.29 \mu \mathrm{g} / \mathrm{mL}$ in DPPH and FRAP assay. At extract concentration of $100 \mu \mathrm{g} / \mathrm{mL}$, K. pneumoniae showed the highest susceptibility of $29.04 \pm 0.35 \mathrm{~mm}$, followed by $P$. aeuruginisa $(26.03 \pm 0.41 \mathrm{~mm})$, while S. aureus $(15.08 \pm 0.20 \mathrm{~mm})$ was least susceptible. The serum concentrations of alanine transaminase (ALT), aspartate transaminase (AST), alkaline phosphatase (ALP), sodium, albumin, total proteins and the computed organs/body weight ratios compared favorably $(p>0.05)$ with control at all extract doses tested. The bilirubin, urea and creatinine levels significantly $(p<0.05)$ increase while chloride decreases in rats dosed $600 \mathrm{mg} / \mathrm{kg}$ bwt. However, potassium level increases significantly $(p<0.05)$ in rats dose $300 \mathrm{mg} / \mathrm{kg}$ of the extract when compare with the control.

Conclusion: This study revealed the strong antioxidant and antimicrobial potentials of methanol extract of Nigerian Zingiber officinale. It was also found to be relatively safe for consumption and thus could serve as a source of candidate for the development of new antioxidants and antimicrobial drugs.
\end{abstract}

Keywords: Anti-oxidants, Antibacterial, Toxicity, Phenolics, Flavonoids Zingiber officinale

\footnotetext{
* Correspondence: bashirlawal12@gmail.com

${ }^{2}$ Department of Biochemistry, Federal University of Technology, P.M.B.65,

Minna, Nigeria

Full list of author information is available at the end of the article
} 


\section{Background}

A major challenge in global health care is the need for novel, effective and affordable medicines to treat microbial infections, especially in developing countries of the world, where up to one-half of deaths are due to infectious diseases [1]. Ethnomedicines constitute a noteworthy part of indigenous knowledge systems of human health management worldwide. They are cost effective, easy to administer and have no prominent resistance [2]. Antimicrobial agents from medicinal plants after possible manipulation may provide new and improved drugs to treat the infectious diseases [3]. On other hand, oxidative stress is the major implicative factors in etiology of certain degenerative and chronic diseases including diabetes, atherosclerosis, parkinsons disease, renal disorders, cardiovascular, inflammatory, cancer, autoimmune, neurodegenerative diseases, and several other human ailments [4].

Different extracts from African medicinal plants have been tested to identify the source of the therapeutic effects [5-7]. As a result some natural products have been approved as new antioxidants and antibacterial drugs, but there is still an urgent need to identify novel substances that are safe, inexpensive and active towards free radicals and pathogens with high resistance [8]. A major hindrance to the development of ethnomedicine in Africa is the poor toxicological profiling of plant materials used as nutraceuticals. However, recent research effort on African plants of medical importance is gradually improving knowledge gaps [9].

Zingiber officinale is a rhizome commonly consumed as a delicacy, medicine or spice [10] Ginger is a strong antioxidant substance and may either mitigate or prevent generation of free radicals. It has been reported for antioxidants and protective role against toxicants, insecticidal, antimicrobial and antiprotozoal activities [11-14]. It has also been recently been reported to improve growth performances in experimental animals [15]. It is considered as a safe herbal medicine with only few and insignificant side effects [16]. However, phytoconstituent, biological activities as well as toxicological virtues of natural products have been reported to vary with geographical origin of the plants [17]. Literature survey revealed scanty information on antioxidants, antimicrobial and safety evaluation of Nigerian $Z$. officinale, in order to bridge the gap in knowledge. This study evaluates the total phenolic and total flavonoids contents, the antioxidant properties (DPPH and FRAP), the in vitro antimicrobial activities of Nigerian $Z$. officinale as well as its effect on hepatorenal integrity in wister rats.

\section{Methods}

\section{Materials}

Fresh samples of Zingiber officinale was obtained from the Lapai Market in Lapai, Niger State Nigeria and was identified by Botanist at the Department of Biological science Federal University of Technology, Minna (FUTMINNA). Healthy albino rats $(122.45 \pm 7.63)$ were procured from animals holding units of FUTMINNA. They were allowed unrestricted access to rat pellets and water.

\section{Chemicals and reagents}

Ascorbic acid (Merck Co.), 2,2-diphenyl-1-picrylhydrazyl radical (DPPH) (Sigma-Aldrich Co.). All biochemical assay kits were either obtained from Randox Laboratories Ltd., United Kingdom or Agappe Diagnostics, Switzerland. All other chemicals were of analytical grade.

\section{Sample preparation and extraction}

The fresh sample of Zingiber officinale was washed and dried for 2 weeks $\left(37^{\circ} \mathrm{C}\right)$ and finally grounded using a grinder mill. A $50 \mathrm{~g}$ of the plant material was extracted with $200 \mathrm{~mL}$ of methanol using soxhlet apparatus and the resulting extract was concentrated using rotary evaporator.

\section{Screening for secondary metabolites}

The plant extract was analyzed for the presence of some secondary metabolite including alkaloids, terpenes, tannins, saponins, phenols, steroids, phlobatannins and flavonoids using standard procedures [18-20].

\section{Assay for antibacterial activity}

Pseudomonas aeruginosa, Salmonella typhi, Klebsiella pneumonia, Staphylococcus aureus and Escherichia coli were the isolates used for this study. Organisms were isolated using standard methods and maintained on agar slants and refrigerated for further use. Antibacterial activity of the extract was carried out using agar-well diffusion method as described by Tsado et al., [21]. A broth microdilution method [22], was used to determine the minimum inhibitory concentration (MIC) and minimum bactericidal concentration $(\mathrm{MBC})$ of the extract in triplicates.

\section{Antioxidant study \\ Total phenolic and flavonoid contents}

Total phenolic content was analyzed using the FolinCiocalteu colorimetric method [23] Results were expressed as mg gallic acid equivalent (GAE) per gram extract. Total flavonoid content was determined using the aluminum chloride colorimetric method [24]. The results expressed as mg quercetin equivalent (QE) per gram of extract. Each plant extract was prepared in triplicate.

\section{FRAP and DPPH assay}

$\mathrm{DPPH}$ radical scavenging activity of the plant extract at varying concentrations $(2.5-100 \mu \mathrm{g} / \mathrm{mL})$ was measured 
in vitro using 2, 2' - diphenyl-1- picrylhydrazyl (DPPH) assay [25]. While Fe3+ ion reducing power of the sample was evaluated using varying extract concentrations $(2.5-100 \mu \mathrm{g} / \mathrm{mL})$ according to the method of Oyaizu [26]. The extract concentration providing 50\% inhibition $\left(\mathrm{IC}_{50}\right)$ was calculated from the plot of inhibition (\%) against extract concentration. Ascorbic acid at the same concentrations was used as the reference antioxidants.

\section{Toxicological study}

Acute toxicity was carried out as reported according to lorke's [27] method as describe by Amos et al., [28]. In the sub acute toxicity. Twenty five (25) wister rats were randomly grouped into five (A-E) of five animals each. Animals in Groups A-D were orally administered $75,150,300$ and $600 \mathrm{mg} / \mathrm{kg}$ bwt of the extract on daily basis for 4 weeks while those in Group A (control) received distilled water. Procedure described by Akanji et al., [29], was followed during blood sample collection and serum preparation for biochemical analysis.

\section{Biochemical parameters}

Serum activities of alkaline phosphatase (ALP), Aspartate transaminase (AST) and alanine transaminase (ALT) were determined [30,31]. The concentrations of serum total proteins, bilirubins, albumins, urea creatinine, sodium, potassium and chloride were determined using standard methods [32-34].

\section{Statistical analysis}

Values were analyzed using statistical analysis system (SAS). Comparisons between different groups were carried out by analysis of variance, ANOVA $(P<0.05)$. Means differences were separated using Duncan's Multiple Range Test [35].

\section{Result}

\section{Qualitative phytochemicals, total phenol and flavonoid} contents

The qualitative analysis of phytochemicals revealed the presence of phenols, tannins, alkaloids, saponins, glycoside, terpenoids, anthraquinone, flavonoids but absence of phlobatannins (Table 1). Total phenolic content of the extract was recorded to be $15.24 \pm 0.02 \mathrm{mg}$ GAE per $\mathrm{g}$ of sample while the total flavonoid content was $19.84 \pm 0.32 \mathrm{mg} / \mathrm{g}$ catechin equivalent (Table 2 ).

\section{Antioxidants activities}

Both methanol extract of Zingiber officinale and ascorbic acid promoted an inhibition of DPPH radical with increasing concentrations (Fig. 1). However, the percentage inhibition of the DPPH radical by the extract was lower than that of ascorbic acid. $\mathrm{The}^{\mathrm{IC}} \mathrm{C}_{50}$ recorded were
Table 1 Phytochemical compositions of methanol extract of Zingiber officinale

\begin{tabular}{lc}
\hline Phytochemicals & Ginger \\
\hline Total phenol & + \\
Total flavonoids & + \\
Tannins & + \\
Alkaloids & + \\
Saponins & + \\
Glycoside & + \\
Terpenoids & + \\
Anthraquinonne & + \\
\hline
\end{tabular}

Key: + means present and - means absent

$47.05 \pm 2.03 \mu \mathrm{g} / \mathrm{mL}$ and $36.44 \pm 1.78 \mu \mathrm{g} / \mathrm{mL}$ for methanol extract of Zingiber officinale (MEZO) and ascorbic acid respectively (Table 3 ). The ability of extract to transform $\mathrm{Fe}^{3+}$ to $\mathrm{Fe}^{2+}$ as illustrated in Table 4 shows that MZO had low \% FRAP ( $\mathrm{IC}_{50} 89.15 \pm 0.29 \mu \mathrm{g} / \mathrm{mL}$ ) compare to ascorbic $\operatorname{acid}\left(\mathrm{IC}_{50} 24.39 \pm 0.46 \mu \mathrm{g} / \mathrm{mL}\right)$.

\section{Antimicrobial activities}

The antibacterial activity assessed in terms of inhibition zone indicated that, at concentrations of 2550 , $100 \mu \mathrm{g} / \mathrm{mL}$ there were increase zone of inhibitions as the extract concentrations increases (Table 5). Klebsiella pneumoniae showed the highest susceptibility of $29.04 \pm 0.35 \mathrm{~mm}$ at $100 \mu \mathrm{g} / \mathrm{mL}$, followed by $P$. aeuruginisa $(26.03 \pm 0.41 \mathrm{~mm})$, Escherichia coli $(22.45$ $\pm 0.32 \mathrm{~mm})$ and Salmonella typhi $(18.05 \pm 0.21 \mathrm{~mm})$, while the least zone of inhibition of $15.08 \pm 0.20 \mathrm{~mm}$ was recorded in Staphylococcus aureus (Table 5). The MIC and MBC were $25 \mu \mathrm{g} / \mathrm{mL}$ and $50 \mu \mathrm{g} / \mathrm{mL}$ respectively for all the organism except Klebsiella pneumonia with MIC and MBC were $12.5 \mu \mathrm{g} / \mathrm{mL}$ and $50 \mu \mathrm{g} / \mathrm{mL}$ respectively (Table 6 ).

\section{Biochemical parameters}

Methanol extract of Zingiber officinale when administered orally into rats had safe dose of $1600 \mathrm{mg} / \mathrm{kg}$ and $\mathrm{LD}_{50}>5 \mathrm{~g} / \mathrm{kg}$ bw (Table 7). The serum concentrations of ALT, AST, ALP, sodium, albumin and total proteins in rats administered methanol extract of Zingiber officinale compared favorably $(p>0.05)$ with control at all doses. The bilirubin, urea and creatinine levels were significantly higher while chloride concentration was significantly $(p<0.05)$ lowered in rat dosed $600 \mathrm{mg} / \mathrm{kg}$ bwt of

Table 2 Total phenols and flavonoids contents of methanol extract of Zingiber officinale

\begin{tabular}{ll}
\hline Phytochemicals & Contents \\
\hline Total phenol & $15.24 \pm 0.02 \mathrm{mgGAE} / \mathrm{g}$ \\
Total flavonoids & $19.84 \pm 0.32 \mathrm{mg} / \mathrm{g}$ catechin equivalent
\end{tabular}

Values are mean \pm SEM of 3 determinations 


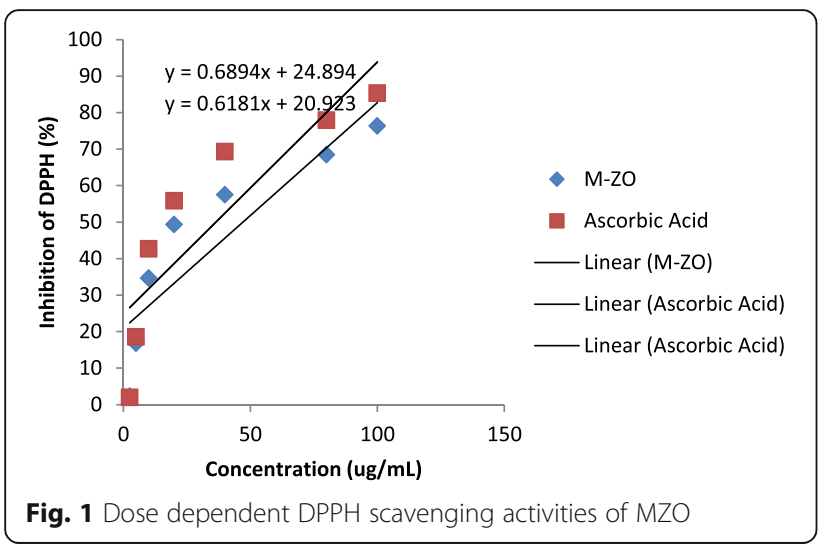

when compared with the control. There was also significant increases $(p<0.05)$ concentration of potassium in rat dose $300 \mathrm{mg} / \mathrm{kg}$ of the extract when compared with the control rats (Table 8). The extract at 75, 150 and $300 \mathrm{mg} / \mathrm{kg}$ b.wt exerted no significant $(p>0.05)$ change in body weight gain. However the group of rat dosed $600 \mathrm{mg} / \mathrm{kg}$ showed lowered weight gain compare to the control. The computed liver, kidney, spleen, heart, and small intestine body weight ratios of the rats were not significantly $(p>0.05)$ different from those of their respective controls (Table 9).

\section{Discussion}

Search for potent drugs to fight emerging and reemerging diseases is continuing with limited successes. Plants are known to produce secondary metabolite which confers to them some physical characteristic and also defense purposes [36]. However, coincidently, these metabolites have been reported for several medicinal values when taken by animals. The photochemical screening of MZO indicated the presence of phenols, tannins, alkaloids, saponins, glycoside, terpenoids, anthraquinone, flavonoids (Table 1), which have been implicated as major

Table 3 DPPH radical scavenging activities of methanol extract of Zingiber officinale

\begin{tabular}{lll}
\hline Conc. $(\mu \mathrm{g} / \mathrm{mL})$ & M-ZO & Ascorbic Acid \\
\hline 2.5 & $2.34 \pm 0.93$ & $1.98 \pm 0.04$ \\
5 & $16.85 \pm 1.24$ & $18.56 \pm 1.64$ \\
10 & $34.65 \pm 2.34$ & $42.73 \pm 3.45$ \\
20 & $49.39 \pm 2.35$ & $55.89 \pm 3.21$ \\
40 & $57.54 \pm 3.56$ & $69.34 \pm 4.34$ \\
80 & $68.46 \pm 5.56$ & $77.94 \pm 2.34$ \\
100 & $76.39 \pm 3.45$ & $85.34 \pm 4.32$ \\
$\mathrm{IC}_{50}$ & $47.05 \pm 2.03$ & $36.44 \pm 1.78$ \\
\hline
\end{tabular}

Values are mean \pm SEM of 3 determinations
Table 4 FRAP activity of leaf extract of methanol extract of Zingiber officinale

\begin{tabular}{lll}
\hline Conc. $\mu \mathrm{g} / \mathrm{mL}$ & $\mathrm{MZO}$ & A. Acid \\
\hline 100 & $54.89 \pm 0.94$ & $93.95 \pm 1.05$ \\
80 & $42.97 \pm 0.39$ & $84.08 \pm 1.67$ \\
40 & $31.78 \pm 0.56$ & $78.40 \pm 0.533$ \\
20 & $24.78 \pm 0.28$ & $60.56 \pm 0.59$ \\
10 & $17.97 \pm 0.95$ & $43.03 \pm 0.75$ \\
50 & $11.08 \pm 0.12$ & $29.79 \pm 0.84$ \\
2.5 & $5.76 \pm 0.32$ & $18.68 \pm 0.92$ \\
$\mathrm{IC}_{50}$ & $89.15 \pm 0.29$ & $24.39 \pm 0.46$ \\
\hline
\end{tabular}

Values are mean \pm SEM of 3 determinations

antioxidants and antimicrobial bioactive compounds from natural products. Previous phytochemical study have documented the presence of only saponin and flavonoids but absence of phlobatanins, terpenoids, anthraquinones, tannins, glycosides, steroids, alkaloids, phenolics in aqueous extract of Zingiber officinale [37]. The great discrepancy in the phytoconstituents could be attributed to the geographical origin of the plant: the plant reported in this study was obtain from northern Nigeria as oppose to that use by Suleiman et al., [37], which was obtained from western Nigeria. Similarly, differences in the polarity of the solvent use could be responsible for the high discrepancy. Lawal et al. [38] also reported that phytochemical composition of medicinal plants can be rationalized in terms of the organ of the plant use as well as the solvent use in the extraction process.

Antimicrobial activity of MZO obtained against $S$. aureus, S. typhi, P. aeuruginisa, K. pneumonia and $E$. coli brought to light differences in sensitivity of organism to antimicrobial agents in plant. It is obvious that the most intense activity was against $K$. pneumoniae $(29.04 \pm 0.35 \mathrm{~mm})$ while the least activity was against Staphylococcus aureus which produced the zone of inhibition of $15.08 \pm 0.20 \mathrm{~mm}$ against that of

Table 5 Susceptibility of the test organisms to various concentrations of methanol extract of Zingiber officinale

\begin{tabular}{llll}
\hline Test organism & \multicolumn{4}{l}{ Zone of Inhibition $(\mathrm{mm})$} \\
\hline & $25 \mu \mathrm{g} / \mathrm{mL}$ & $50 \mu \mathrm{g} / \mathrm{mL}$ & $100 \mu \mathrm{g} / \mathrm{mL}$ \\
P. aeuruginisa & $12.10 \pm 0.30$ & $18.23 \pm 0.22$ & $26.03 \pm 0.41$ \\
Klebsiella pneumoniae & $16.44 \pm 0.25$ & $22.34 \pm 0.28$ & $29.04 \pm 0.35$ \\
Salmonella typhi & $18.90 \pm 0.24$ & $21.18 \pm 0.19$ & $18.05 \pm 0.21$ \\
Staphylococcus aureus & $7.34 \pm 0.12$ & $17.56 \pm 0.21$ & $15.08 \pm 0.20$ \\
Escherichia coli & $17.04 \pm 0.21$ & $18.45 \pm 0.18$ & $22.45 \pm 0.32$ \\
Control & $13.14 \pm 0.82$ & $19.24 \pm 0.28$ & $25.24 \pm 0.29$ \\
\hline
\end{tabular}

Values are Mean \pm SEM of triplicate determinations 
Table 6 Minimum inhibitory concentration (MIC) and minimum bactericidal concentration (MBC) of the extract

\begin{tabular}{lll}
\hline Test organism & $\mathrm{MIC} \mu \mathrm{g} / \mathrm{mL}$ & $\mathrm{MBC} \mu \mathrm{g} / \mathrm{mL}$ \\
\hline P. aeuruginisa & 25 & 50 \\
Klebsiella pneumoniae & 12.5 & 50 \\
Salmonella typhi & 25 & 50 \\
Staphylococcus aureus & 25 & 50 \\
Escherichia coli & 25 & 50 \\
\hline
\end{tabular}

ampicillin $(25.24 \pm 0.67 \mathrm{~mm})$. The methanol extract of $Z$. officinale exerted significant level of inhibition against both the Gram positive and Gram negative bacteria and thus can be considered as plant with broad spectrum activity. The antimicrobial activities recorded in this study is far better than activities reported in previous study [37], where the authors reported aqueous extract of Zingiber officinale at $200 \mathrm{mg} / \mathrm{mL}$ had no inhibitory activities against $K$. pneumonia and $E$. coli but little activities against $S$. aureus $(13.5 \mathrm{~mm})$ and E.coli $(15.5 \mathrm{~mm})$. This discrepancy is obviously related to the differences in polarity of the extraction solvents. The aqueous extraction may not be efficient enough to extract antimicrobial agent from Zingiber officinale. Afolayan et al., [39] also reported that most active antimicrobial components are generally insoluble in aqueous medium, thus it is expected that organic solvents of low polarity would yield more active antimicrobial extracts. Similarly, Aliero et al. [40], and Ashafa et al. [41], also reported that methanol extract of plants generally have higher antimicrobial activities than the aqueous extract which, sometimes showed little or no antibacterial activities.

There has been renewed interest in the role of African traditional plants for the treatment of oxidative stress induces diseases [5]. In our study to show the antioxidant activity of Zingiber officinale, methanol extract of Zingiber officinale promoted an inhibition of DPPH radical and the transformation of $\mathrm{Fe}^{3+}$ to $\mathrm{Fe}^{2+}$ in a dose dependent fashion. In $\mathrm{DPPH}$ assay the extract had $\mathrm{IC}_{50}$ values of $47.05 \pm 2.03 \mu \mathrm{g} / \mathrm{mL}$ higher than $\mathrm{IC}_{50}$ of
$25.11 \mu \mathrm{g} / \mathrm{mL}$ previously reported for cyclohexane extract but lower than $\mathrm{IC}_{50}$ of $83.00 \mu \mathrm{g} / \mathrm{mL}$ and $81.00 \mu \mathrm{g} / \mathrm{mL}$ reported for ethanol and acetone extracts of Iraq Zingiber officinale [16]. The ability of extract to transform $\mathrm{Fe}^{3+}$ to $\mathrm{Fe}^{2+}$ as depicted in Table 4 shows that MZO had low \% FRAP $\left(\mathrm{IC}_{50} 89.15 \pm 0.29 \mu \mathrm{g} / \mathrm{mL}\right)$ compare to ascorbic $\operatorname{acid}\left(\mathrm{IC}_{50} 24.39 \pm 0.46 \mu \mathrm{g} / \mathrm{mL}\right)$. However, this activity recorded may also serve as a significant indicator of its potentials in managements of free radical dilemma. Among the several classes of phytochemicals, phenolic and flavonoids have been implicated in the antioxidant effect of natural products [42]. Total phenolic and total flavonoid contents of Zingiber officinale were recorded to be $15.24 \pm 0.02 \mathrm{mg} \mathrm{GAE} / \mathrm{g}$ and $19.84 \pm 0.32 \mathrm{mg} / \mathrm{g}$ catechin equivalent (Table 2). These significant amounts of flavonoids and phenols recorded in this study could be responsible for the observed free radical scavenging activity of the plant extract.

Liver is one of the most important organs, whose major activities are maintaining homeostatis and metabolism of drugs/chemicals/toxicants that are introduced to the body system, thus making it highly susceptible to impairment [5]. Evaluation of biochemical parameters; ALT, AST, ALP, albumin bilirubins and total proteins are therefore relevant in assessing the integrity of liver following administration of plants extracts. Alterations in the normal activities or concentrations of these parameters are conventional indicators of hepatocellular injury, cellular leakage, loss of functional integrity of cell membrane, liver hepatitis, biliary cirrhosis, and in diseases characterized by inflammation, intrahepatic and extrahepatic bile obstruction [43]. Interestingly, 28 days administration of methanol extract of Zingiber officinale at concentrations of $75 \mathrm{mg} / \mathrm{kg}-600 \mathrm{mg} / \mathrm{kg}$ bwt did not cause any significant alterations to the serum concentrations of serum ALT, AST, ALP, albumin and total proteins when compared with the control values. This simply implies that the functional integrity of liver has not been compromised.

The serum levels of electrolytes, urea, total protein, bilirubin, albumin and creatinine are indicator of synthetic secretory, and excretory role of the liver and kidney [44]. The observed increase in bilirubin

Table 7 Acute toxicity profile of Crude methanol extract of Zingiber officinale in rat

\begin{tabular}{ll}
\hline Dose (mg/kgbwip) & Observations \\
\hline 10 & Normal/no unusual reactions \\
100 & Normal/no unusual reactions \\
1000 & Normal/no unusual reactions \\
1600 & Normal/no unusual reactions \\
2900 & Lacrimation/hyperactivity/restlessness and slight erythema. \\
5000 & intense erythema, tarchycardia and disorientation. \\
\hline
\end{tabular}


Table 8 Effects of methanol extract of Zingiber officinale on serum biochemical parameters and body weight gain in rats

\begin{tabular}{|c|c|c|c|c|c|}
\hline & \multicolumn{4}{|c|}{ Extract concentration (mg/kg bwt) } & \multirow[b]{2}{*}{ Control } \\
\hline & 75 & 150 & 300 & 600 & \\
\hline$\overline{\text { Protein }(\mathrm{mg} / \mathrm{dl})}$ & $39.42 \pm 2.34^{a}$ & $41.23 \pm 3.45^{a}$ & $40.18 \pm 3.41^{a}$ & $39.58 \pm 3.66^{\mathrm{a}}$ & $37.57 \pm 2.78^{a}$ \\
\hline Bilirubin (mg/dl) & $4.53 \pm 0.34^{a}$ & $5.32 \pm 0.78^{\mathrm{a}}$ & $5.04 \pm 0.21^{\mathrm{a}}$ & $7.70 \pm 0.45^{b}$ & $5.32 \pm 0.46^{\mathrm{a}}$ \\
\hline Albumin (mg/dl) & $3.76 \pm 0.78^{\mathrm{a}}$ & $3.97 \pm 0.56^{\mathrm{a}}$ & $3.91 \pm 0.06^{\mathrm{a}}$ & $3.47 \pm 0.24^{\mathrm{a}}$ & $3.43 \pm 0.36^{\mathrm{a}}$ \\
\hline $\mathrm{ALT}(\mathrm{U} / \mathrm{L})$ & $5.43 \pm 0.56^{\mathrm{a}}$ & $5.65 \pm 0.45^{\mathrm{a}}$ & $5.10 \pm 0.34^{a}$ & $5.40 \pm 0.44^{\mathrm{a}}$ & $5.45 \pm 0.24^{\mathrm{a}}$ \\
\hline AST(U/L) & $25.45 \pm 2.45^{\mathrm{a}}$ & $28.05 \pm 1.56^{\mathrm{a}}$ & $25.70 \pm 1.34^{\mathrm{a}}$ & $28.33 \pm 1.45^{\mathrm{a}}$ & $28.30 \pm 2.35^{\mathrm{a}}$ \\
\hline $\mathrm{ALP}(\mathrm{U} / \mathrm{L})$ & $142.34 \pm 5.67^{\mathrm{a}}$ & $138.45 \pm 2.56^{\mathrm{a}}$ & $145.03 \pm 2.56^{\mathrm{a}}$ & $139.75 \pm 4.56^{\mathrm{a}}$ & $141.35 \pm 3.56^{\mathrm{a}}$ \\
\hline Creatinine & $10.68 \pm 1.23^{\mathrm{a}}$ & $10.42 \pm 0.45^{\mathrm{a}}$ & $11.6 \pm 0.95^{\mathrm{a}}$ & $14.21 \pm 0.34^{\mathrm{b}}$ & $11.34 \pm 0.45^{\mathrm{a}}$ \\
\hline Urea & $27.54 \pm 4.56^{\mathrm{a}}$ & $30.45 \pm 1.23^{\mathrm{ab}}$ & $26.73 \pm 2.67^{\mathrm{a}}$ & $37.32 \pm 3.45^{b}$ & $26.78 \pm 2.46^{\mathrm{a}}$ \\
\hline Chloride & $367.45 \pm 9.87^{b}$ & $395.56 \pm 8.67^{b}$ & $398.54 \pm 11.56^{\mathrm{b}}$ & $238.70 \pm 7.81^{\mathrm{a}}$ & $378.0 \pm 9.87^{b}$ \\
\hline Potassium & $5.32 \pm 0.68^{\mathrm{a}}$ & $5.65 \pm 0.34^{\mathrm{a}}$ & $7.76 \pm 1.02^{b}$ & $5.28 \pm 0.45^{\mathrm{a}}$ & $5.54 \pm 0.45^{a}$ \\
\hline Sodium & $22.56 \pm 3.46^{a}$ & $27.84 \pm 3.67^{\mathrm{a}}$ & $23.33 \pm 3.56^{\mathrm{a}}$ & $25.6 \pm 2.86^{\mathrm{a}}$ & $24.56 \pm 1.35^{\mathrm{a}}$ \\
\hline Initial Body weight (g) & $128.45 \pm 3.69^{b}$ & $137.78 \pm 5.75^{b}$ & $138.15 \pm 2.17 a$ & $115.50 \pm 2.35^{\mathrm{a}}$ & $125.67 \pm 2.34^{a}$ \\
\hline Final Body weight (g) & $158.23 \pm 3.67^{b}$ & $169.45 \pm 4.92^{b}$ & $166.58 \pm 2.15^{b}$ & $137.35 \pm 1.57^{\mathrm{b}}$ & $154.92 \pm 2.79^{b}$ \\
\hline Weight gain (g) & 29.78 & 31.67 & 28.34 & 21.85 & 29.25 \\
\hline
\end{tabular}

Values are mean \pm SEM of 5 determinations. Values along the same row with same superscripts alphabets are not significantly different $(p<0.05)$

content in rats' dose $600 \mathrm{mg} / \mathrm{kg}$ b.wt suggests a compromise of the synthetic ability of the liver. The extract might have increased the functional activity of the liver by interfering with the equilibrium in the rate of synthesis and destruction, removal or clearance of bilirubin from the system of the animals [45]. Such increase in bilirubin could, negatively affect the metabolic activities of the liver and consequently the health of the animals.

The kidneys regulate the excretion of urea and reabsorption of electrolytes into the blood. During glomerular impairment, urea and creatinine accumulate in the biological fluid [46]. In the present study, the significant alterations in serum urea and creatinine concentrations following the administration of the extract could be due renal dysfunction. The extract at high dose (600 mg/kg bwt) might have either interfered with creatinine metabolism leading to increased synthesis or the tissue might have compromised all or part of its functional capacity of tubular excretion [45]. Similarly, the significantly $(p>0.05)$ decrease in the concentrations of chloride in rats dosed $600 \mathrm{mg} / \mathrm{kg}$ bwt of Zingiber officinale when compared with the control is an indication that the normal function of the kidney as regard to this metabolites has been compromised. This therefore suggests that the continuous administration of Zingiber officinale at dose of $600 \mathrm{mg} / \mathrm{kg}$ b.wt could cause renal damage.

Although, there was significant increases $(p<0.05)$ in concentrations of potassium in rat dosed $300 \mathrm{mg} / \mathrm{kg}$ b.wt of the extract when compare with the control rat. The severe alterations in urea, creatinine, bilirubin and other electrolyte that were recorded in rats dosed $600 \mathrm{mg} / \mathrm{kg}$ bwt were absent in rats dosed 75, 150, and $300 \mathrm{mg} / \mathrm{kg}$ b.wt of the extract, thus, point out the safety of Zingiber officinale at doses of 75, 150, and $300 \mathrm{mg} / \mathrm{kg}$ b.wt. According to Berinyuy et al. [47], organ/body weight ratios are good indicator of organs inflammation or constriction. The absence of an effect on the computed organs/body weight ratios suggests that the extract did not cause any form of swelling, atrophy and hypertrophy on the organs.

Table 9 Relative organ weight ratio of rats administered methanol extract of Zingiber officinale

\begin{tabular}{|c|c|c|c|c|c|c|}
\hline GROUPS & Liver & Heart & Intestine & Lungs & Kidney & Spleen \\
\hline 75 mg/kg b.wt MZO & $2.04 \pm 0.56^{a}$ & $0.39 \pm 0.00^{\mathrm{a}}$ & $2.42 \pm 0.17^{\mathrm{a}}$ & $0.75 \pm 0.01^{a}$ & $0.96 \pm 0.02^{a}$ & $0.39 \pm 0.12^{a}$ \\
\hline 150 mg/kg b.wt MZO & $2.19 \pm 0.29^{a}$ & $0.42 \pm 0.01^{a}$ & $2.02 \pm 0.01^{\mathrm{a}}$ & $0.78 \pm 0.01^{a}$ & $0.99 \pm 0.00^{\mathrm{a}}$ & $0.42 \pm 0.21^{a}$ \\
\hline 300 mg/kg b.wt MZO & $2.01 \pm .0 .24^{\mathrm{a}}$ & $0.38 \pm 0.03^{a}$ & $2.01 \pm 0.04^{\mathrm{a}}$ & $0.80 \pm 0.02^{\mathrm{a}}$ & $0.98 \pm 0.01^{a}$ & $0.44 \pm 0.09^{a}$ \\
\hline 500 mg/kg b.wt MZO & $2.57 \pm .0 .22^{\mathrm{a}}$ & $0.42 \pm 0.01^{a}$ & $2.02 \pm 0.15^{\mathrm{a}}$ & $0.79 \pm 0.03^{a}$ & $0.92 \pm 0.00^{\mathrm{a}}$ & $0.39 \pm 0.44^{a}$ \\
\hline CONTROL & $2.34 \pm 0.13^{\mathrm{a}}$ & $0.41 \pm 0.02^{\mathrm{a}}$ & $2.34 \pm 0.25^{\mathrm{a}}$ & $0.84 \pm 0.00^{\mathrm{a}}$ & $0.93 \pm 0.00^{\mathrm{a}}$ & $0.37 \pm 0.01^{a}$ \\
\hline
\end{tabular}

Values are mean \pm SEM of 5 determinations. Values along the same row with different superscripts are significantly different $(p<0.05)$ 


\section{Conclusion}

In conclusion, the methanol extract of Zingiber officinale has antioxidant and antimicrobial properties and could be employed as a source of candidate for the development of new antioxidants and antimicrobial drugs. The extract at $75-300 \mathrm{mg} / \mathrm{kg}$ b.wt also cause no significant alteration to the normal level of serum biochemical parameters and thus could be considered safe for consumption and clinical applications.

\section{Abbreviations \\ ALP: Alkaline phosphatase; ALT: Alanine aminotransferase; AST: Aspartate amino transferase; b.wt: Body weight; CRT: Creatinine; DB: Direct bilirubin; DPPH: 2, 2'- diphenyl-1- picrylhydrazyl; FRAP: Fe ${ }^{2+}$ chelating ability and ferric reducing antioxidant properties; GAE: Garlic acid equivelent; MZO: Methanol extract of Zingiber officinale; TB: Total bilirubin}

\section{Funding}

This work is sponsored sorely by the authors. No source of funding from any organization.

\section{Availability of data and materials}

All relevant data are presented in the manuscript.

\section{Authors' contributions}

This work was carried out in collaboration between all authors. Author AAY, $B L, A N B, E B B$ design and carried out the practical work. Authors SIU, MNS, YMA participate in the lab work. Authors BL, ANB, EBB, SIU, MNS, YMA did the literature search, data analysis and preparation of the manuscript. All authors read and approved the final manuscript.

\section{Ethics approval}

The principles governing the use of laboratory animals as laid out by the Federal University of Technology, Minna Committee on Ethics for Medical and Scientific Research and also existing internationally accepted principles for laboratory animal use and care as contained in the Canadian Council on Animal Care Guidelines and Protocol Review were duly observed.

\section{Consent for publication}

\section{Not applicable}

\section{Competing interests}

The authors declare that they have no competing interests.

\section{Author details}

'Department of Biochemistry, IBB University Lapai, Lapai, Niger State, Nigeria. 2Department of Biochemistry, Federal University of Technology, P.M.B.65, Minna, Nigeria. ${ }^{3}$ Faculty of medicine and biomedical sciences, University of Yaounde 1, Yaounde, Cameroon. ${ }^{4}$ Federal Polytechnic, Ile-Oluji, P.M.B. 727, Ile Oluji, Ondo State, Nigeria.

\section{Received: 28 December 2017 Accepted: 6 March 2018}

/ Published online: 04 May 2018

\section{References}

1. Elisha LL, Botha FS, McGaw LJ, Eloff JN. The antibacterial activity of extracts of nine plant species with good activity against Escherichia coli against five other bacteria and cytotoxicity of extracts. BMC Compl Altere Med. 2017;17: 133. https://doi.org/10.1186/s12906-017-1645-z.

2. Mudzengia CP, Murwiraa A, Tivapasic MT, Murungwenid C, Joan V, Burumue VB, Halimanif T. Antibacterial activity of aqueous and methanol extracts of selected species used in livestock health management. Pharm Biol. 2017;55(1):1054-60.

3. Ali SS, Ayub A, Ali SN, Begum S, Siddiqui BS, Mahmood M, Khan KL. Antibacterial activity of methanolic extracts from some selected medicinal plants FUUAST. J Biol. 2017;7(1):123-5.

4. Mzid M, Ben Khedir S, Ben Salem M, Regaieg W, Rebai T. Antioxidant and antimicrobial activities of ethanol and aqueous extracts from Urtica urens. Pharm Biol. 2017;55(1):775-81. https://doi.org/10.1080/13880209.2016. 1275025.
5. Lawal B, Shittu OK, Inje OF, Berinyuy EB, Muhammed H. Potential antioxidants and Hepatoprotectives from African natural products: a review. Clin Phytoscience. 2016;2:23. https://doi.org/10.1186/s40816-016-0037-0.

6. Lawal B, Shittu OK, Kabiru AY, Jigam AA, Umar MB, Berinyuy EB, et al. Potential antimalarials from African natural products: a review. J Intercult Ethnopharmacol. 2015;4(4):318-43.

7. Bashir L, Shittu OK, Sani S, Busari MB, Adeniyi KA. African natural products with potential antitrypanosoma properties: a review. Int J Biochem Res Rev. 2015;7:45-79.

8. Deshpande B, Varsha C, Bhawana PD. Antibacterial activity of plant extract of amaranthus spinosus. Indian JSciRes. 2017;12(2):041-4.

9. Ogbunugafor HA, Ugochukwu CG, Kyrian-Ogbonna AE. The role of spices in nutrition and health: a review of three popular spices used in southern Nigeria. Food Quality and Safety. 2017;1(3):171-85. https://doi.org/10.1093/ fasafe/fyx020

10. Dhanik J, Neelam A, Viveka NA. Review on Zingiber officinale. Journal of Pharmacognosy and Phytochemistry. 2017:6(3):174-84.

11. Sharma Y. Ginger (Zingiber officinale)-an elixir of life a review. The Pharma Innovation J. 2017;6(10):22-7.

12. Hasona NA, Mohammed Q. Ahmed antioxidant and ameliorative effects of Zingiber Officinale against aluminum chloride toxicity. Science International. 2017;5(3):96-104.

13. Hosseinzadeh A, B Bahrampour JK, Fatemi MJ, Kamarul T, · Bagheri A Tekiyehmaroof NS. Protective effect of ginger (Zingiber officinale roscoe) extract against oxidative stress and mitochondrial apoptosis induced by interleukin-1 $\beta$ in cultured chondrocytes. Cells Tissues Organs 2017;204:241-250 (https://doi. org/10.1159/000479789).

14. Azhari HN, Sook SY, Abdurahman HN. Extraction and chemical compositions of ginger (Zingiber Officinale roscoe) essential oils as cockroaches repellent. Australian J Basic and Appl Sci. 2017:11(3):1-8.

15. Ogueji EO, Iheanacho SCI, Dada AO, Yaji AJ, Ifejimalu A, Ibrahim BU, Mbah EC, Okafor EA, Nnatuanya IO. Effect of Roselle (Hibiscus sabdariffa) and ginger (Zingiber officinale) as feed additives, on growth and haematology of Clarias gariepinus juvenile. African Journal of Biotech. 2017;16(48):2242-7.

16. Aziz DM, Wsoo MA, Ibrahim BM. Antimicrobial and antioxidant activities of extracts from medicinal plant ginger (Zingiber officinale) and identification of components by gas chromatography. African J Plant Scie. 2015;9(10):412-20.

17. Lawal B, Shittu OK, Abubakar AN, Olalekan IZ, Jimoh AM, Abdulazeez AK. Drug leads agents from methanol extract of Nigerian bee (Apis mellifera) Propolis. J Intercult Ethnopharmacol. 2016;5(1) https://doi.org/10.5455/jice. 20150928102856

18. Harborne JB. Phytochemical methods. A guide to modern techniques of plant analysis, vol. 13. London, New York: Chapman and Hall Ltd; 1973. p. 49-188.

19. Trease GE, Evans WC. Pharmacognosy. 11th ed. London: Brailliar Tiridel CanMacmillan Publishers; 1989. p. 60-75. 14

20. Sofowora AE. Recent trends in research into African medicinal plants. J Ethnopharmacol. 1993;389:209-14.

21. Tsado NA, Lawal B, Ossa PC, Jagaba A, Kontagora GN, Gboke JA, Umar AM, Oladunjoye JO. Antioxidants and antimicrobial activities of methanol extract of Newbouldia laevis and Crateva adansonii. J Pharm Allied Health Sci. 2016; https://doi.org/10.3923/jpahs.2016.

22. Eloff JN. A sensitive and quick microplate method to determine the minimal inhibitory concentration of plant extracts for bacteria. Planta Med. 1998;64:711-3.

23. Chlopicka J, Pasko P, Gorinstein S, Jedryas A, Zagrodzki P. Total phenolic and total flavonoid content, antioxidant activity and sensory evaluation of pseudocereal breads. LWT-Food Sci Technol. 2012;548-55(16):46.

24. Stanković MS. Total phenolic content, flavonoid concentration and antioxidant activity of Marrubium peregrinum L. extracts. Kragujevac J Sci. 2011;33:63-72.

25. Blois MS. Antioxidant determinations by the use of a stable free radical. Nature. 1958;181:1199-200.

26. Oyaizu M. Studies on products of browning reaction-antioxidative activities of products of browning reaction prepared from glucosamine. Jpn J Nutr. 1986;44:307-15

27. Lorke D. A new approach to practical acute toxicity testing. Arch Toxicol. 1983:53:275-87.

28. Amos TN, Bashir L, Saba SE, Saba MA, Mohammed BM, Abdulsalam IH, et al. Phytochemicals and acute toxicity profile of aqueous and methanolic extracts of Crateva adansonii leaves in Swiss albino rats. Asian. J Biochem. 2015;10(4):173-9. 
29. Akanji MA, Salau AK, Yakubu MT. Safety evaluation of aqueous extract of Crateva adansonii leaves on selected tissues of rats. Fount J Nat Appl Sci. 2013;2(1):17-28.

30. Tietz NW. Clinical guide to laboratory tests. 3rd ed. Philadelphia, PA: WB Saunders Company; 1995. p. 286-8.

31. Reitman S, Frankel S. A colorimetric method for the determination of serum glutamic oxalacetic and glutamic pyruvic transaminases. Am J Clin Pathol. 1957;28:56-63.

32. Gornall AC, Bardawill CJ, David MM. Determination of serum protein by means of biuret reaction. J Biol Chem. 1949;177:751-66.

33. Doumas BT, Watson WA, Biggs HG. Albumin standards and the measurement of serum album with bromocresol green. Clin Chem Acta. 1971:31:87-96.

34. Blass KG, Thierbert RJ, Lam LK. A study of the mechanism of the Jaff'e reaction. Z Klin Chem Klin Biochem. 1974;12:336-43.

35. SAS. Statistical analysis system, SAS users guide: statistics. Cary: SAS institute Inc; 2008

36. Abalaka ME, Akpor OB, Bello AB, Olonitola OS, Sani A, Osemwegie OO Synthesis of silver nanoparticles (agnps) from bark and root of african mahogany (khaya senegalensis) and the comparative studies of their antimicrobial properties. Asian J Microb Biotech. 2016;1 (1):25-32.

37. Sulaimana FA, Kazeemb MO, Waheeda AM, Temowoa SO, Azeeza IO, Zubaira Fl, Adeyemib TA, Nyangb A, Adeyemi OS. Antimicrobial and toxic potential of aqueous extracts of Alliumsativum, Hibiscus sabdariffa and Zingiber officinale in Wistar rats. Journal of Taibah University for Science. 2014;8:315-22. Available online at www.sciencedirect.com

38. Lawal B, Ossai PC, Shittu OK, Abubakar AN. Evaluation of phytochemicals, proximate, minerals and anti-nutritional compositions of yam peel, maize chaff and bean coat. Inter Appl Biol Res. 2014;6(2):01-17.

39. Afolayan CO, Onifade AK, Akinde PO. Antimicrobial activity of Emilia pratermissa leaf extracts on organisms isolated from patients with otitis media attending Federal Medical Centre Owo and Ondo states specialist hospital Akure. Microbiol. Res. J Int. 2017;19(1):1-8.

40. Aliero AA, Grierson DS, Afolayan AJ. Antifungal activity of Solanum pseudocapisum. Res J Bot. 2006;1:129-33.

41. Ashafa AO, Grierson DS, Afolayan AJ. Antimicrobial activity of extract from Felicia muricata Thunb. J Biol Sci. 2008;8(6):1062-6.

42. Köksal E, Tohma T, Kılıç O, Alan Y, Aras A, Gülçin I, Bursal E. Assessment of antimicrobial and antioxidant activities of Nepeta trachonitica: analysis of its phenolic compounds using HPLC-MS/MS. Sci Pharm 2017, 85, 24; https://doi.org/10.3390/scipharm85020024.

43. Ikanone CEO, Akinloye OA, Augbaja RN, Omotainse SO, Ajayi OL, Shopein TM. Effect of sub-acute exposure to bonny light crude oil on plasma biochemistry and liver histopathology of albino rat. Animal Res Inter. 2017 14(1):2652-9.

44. Shittu OK, Lawal B, Abubakar NA, Berinyuy BE, Busari MB, Ibrahim AO. Toxicological implications of methanol extract from Nigerian bee propolis on some selected rat tissues. J Pharm Biomed Sci. 2015:5(7):524-31.

45. Bashir L, Shittu OK, Busari MB, Sani S, Aisha MI. Safety evaluation of giant African land snails (Archachatina maginata) haemolymph on hematological and biochemical parameters of albino rats. J Adv Med Pharm Sci. 2015;3(3): 122-30.

46. Shittu OK, Lawal B, Alozieuwa BU, Haruna GM, Abubakar AN, Berinyuy EB. Alteration in biochemical indices following chronic administration of methanolic extract of Nigeria bee propolis in Wister rats. Asian Pac J Trop Dis. 2015;5(8):654-7.

47. Berinyuy EB, Lawal B, Olalekan AA, Olalekan IA, Yusuf AA, Sakpe S, et al. Hematological status and organs/body-weight parameters in Wister rats during chronic administration of Cassia occidentalis. Int Blood Res Rev. 2015; 4(3):1-7.

\section{Submit your manuscript to a SpringerOpen ${ }^{\circ}$ journal and benefit from:}

- Convenient online submission

- Rigorous peer review

- Open access: articles freely available online

- High visibility within the field

- Retaining the copyright to your article

Submit your next manuscript at springeropen.com 